O. V. KRYVOVIAZ (https://orcid.org/0000-0001-5441-1903),

I. K. SHCHERBA (https://orcid.org/0000-0001-7090-2868),

Yu. O. TOMASHEVSKA (https://orcid.org/0000-0001-9708-1887),

V. V. KUDRIA (https://orcid.org/0000-0001-6613-8035)

Pirogov National Memorial Medical University, Vinnytsya

\title{
STUDENTS' AWARENESS OF BREAST CANCER RISK FACTORS (RESULTS OF A SOCIOLOGICAL STUDY)
}

Key words: breast cancer, risk factors, anonymous survey, questionnaire

О. В. КРИВОВ'ЯЗ (https://orcid.org/0000-0001-5441-1903), д-р фарм. наук, доцент,

I. К. ЩЕРБА (https://orcid.org/0000-0001-7090-2868), канд. біол. наук, доцент,

Ю. О. ТОМАШЕВСЬКА (https://orcid.org/0000-0001-9708-1887), канд. фарм. наук, доцент,

В. В. КУДРЯ (https://orcid.org/0000-0001-6613-8035)

Вінницький національний медичний університет ім. М. І. Пирогова, м. Вінниия

ОБІЗНАНІСТЬ СТУДЕНТОК ЩОДО ФАКТОРІВ РИЗИКУ РАКУ МОЛОЧНОЇ

ЗАЛОЗИ (РЕЗУЛЬТАТИ СОЦІОЛОГІЧНОГО ДОСЛІДЖННЯ)

Ключові слова: рак грудної залози, фактори ризику, анонімне опитування, анкетаопитувальник

The maintaining of reproductive health of the nation is the essential part of Ukraine's demographic policy. Thus, the organization of services and measures aiming to improve prevention, diagnosis and treatment of women who suffer from cancer of reproductive organs remains a pressing issue which has to be addressed at the state level [1].

Breast cancer is the leading type of cancer among female population [2. 3], and, worldwide, it results in over half a million deaths of women every year [2, 4]. According to the data of the National Cancer Registry, in Ukraine the highest number of breast cancer cases is recorded in women over 60 years of age [5], though the prevalence of breast cancer increases already in women age 30 and older $[2,7]$.

One of the most noticeable features characterizing the increase in the number of cases of diagnosed malignancies in women in economically developed countries is the significantly higher occurrence rate of breast cancer that takes the leading position in the cancer incidence and mortality [2]. Thus, the rates of breast cancer incidence and mortality in Ukraine are respectively $45 \%$ and $56 \%$ higher in comparison to the European countries. Such situation is due, in particular, to the fact that Ukrainian women tend to consult a specialist at late stages of the disease, ignore screenings for cancer and neglect to follow strictly the prescribed treatment [3].

Each fourth woman is diagnosed with breast cancer at stage 3 or 4 , when the effectiveness of treatment is greatly reduced [7].

Based on statistics of the National Cancer Institute (USA), early detection of the disease increases the chances for successful treatment in $98.1 \%$ of cases [2].

The aim of our study was to determine the extent of awareness of the breast cancer (BC) prevention methods among the female students of the Pharmaceutical Department of Pirogov National Memorial Medical University as well as to reveal any risk groups for this disease.

\section{Mat e rials and Meth ods}

The survey material consisted of 240 completed questionnaires. The questionnaire consisted of thirteen questions regarding the awareness of risk factors and groups, cases of breast cancer among the respondents' relatives, knowledge about breast self-examination for cancer and breast cancer prevention measures (Fig. 1). The study used sociological and medical-statistical methods.

(C) Колектив авторів, 2019 
The questionnaire was developed on the principles and guidelines of the National Cancer Institute (USA) concerning genetic predisposition, prevention, diagnosis and the course of the BC disease [7].

The Questionnaire Designed to Assess the Extent of Awareness of the Breast cancer (BC) Prevention Methods among the Female Students of the Pharmaceutical Department of National Pirogov Memorial Medical University, Vinnytsia

1. Do you know that certain groups of women are at higher risk of breast cancer?

$\square$ Yes

$\square$ No

$\square$ Difficult to answer

2. Which of the following risk factors for breast cancer are you aware of?

$\square$ Age over 40

$\square$ Breast cancer cases among your family members

$\square$ The first menstruation before the age of 12 and menopause after 55

口 Pregnancy after 30 and lack of childbearing

$\square$ Use of hormone medications

a Unhealthy habits (smoking, excessive alcohol use)

$\square$ Excessive body weight and low physical activity

$\square$ Frequent stress

$\square$ All of the above

3. Have there been cases of breast cancer in your family?

$\square$ My great-grandmother

$\square$ My grandmother

$\square$ My mother

$\square$ My aunt

$\square$ My sister

$\square$ Nobody

4. Do you believe you are at risk for developing this disease?

$\square$ Yes

$\square$ No

$\square$ Difficult to answer

5. Are you familiar with the method of Breast Self-Examination (BSE)?

$\square$ Yes

$\square$ No

$\square$ Difficult to answer

6. Do you practice BSE?

$\square$ Yes

$\square$ Sometimes

$\square$ No

$\square$ Difficult to answer

7. Which measures do you take in everyday life in order to reduce the risk for developing breast cancer?

$\square$ Give up bad habits, especially smoking

$\square$ Increase physical activity

$\square$ Eat a healthy diet

$\square$ Get rid of excess body weight

$\square$ Control your emotional state

$\square$ Visit your gynecologist for regular checkups

$\square$ Try to have children at a young age and breastfeed them

$\square$ All of the above

$\square$ Do nothing

$\square$ Difficult to answer

8. Do you have any breast problems (redness of the skin of the breast, swollen lymph nodes, tenderness, nipple discharge, inverted nipple, etc.)?

$\square$ Yes

$\square$ No

$\square$ Difficult to answer

9. Would you like to do a mammography, a breast ultrasound?

$\square$ Yes

$\square$ No

$\square$ Difficult to answer

10. Would you say that you visit your gynecologist regularly?

$\square$ Yes

$\square$ No

$\square$ Difficult to answer

11. Your age:

$\square$ under 17 years

$\square 17$ - 18 years

$\square 19-20$ years

․․ and older

12. Marital status

$\square$ Married

$\square$ Single

$\square$ Divorced

13. Do you have children?

$\square$ Yes

$\square$ No

Fig. 1. A sample of the questionnaire the respondents were asked to complete 
An anonymous survey was conducted among female students of the Pharmaceutical Department of Pirogov National Memorial Medical University, Vinnytsya (the general population). The statistical analysis of the results of the survey was done in Statistica 10.0 package using the method of calculation of relative values.

Results and D is cussion

The results of the survey reveal a fairly uniform distribution by age: almost $43.3 \%$ of the participants $(104 / 240)$ were 19-20 years old, 36.7\% (88/240) - 17-18 years of age, $20.0 \%$ (48/240) of the respondents were over 21 (Fig. 2).

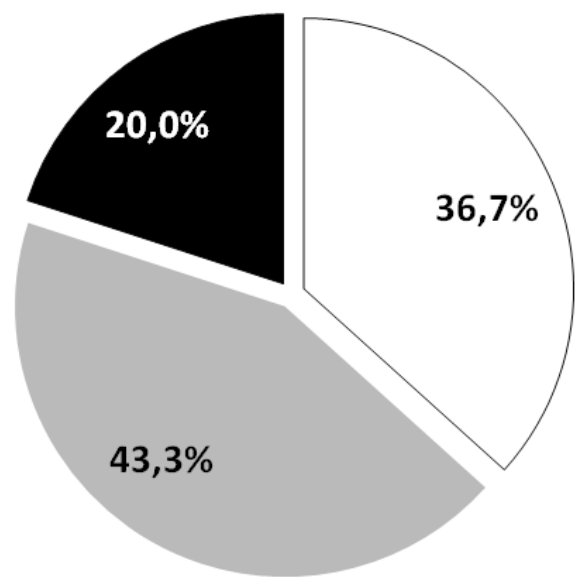

$\square$ 17-18years of age $\square$ 19-20years old $\quad$ over 21

Fig. 2. Distribution of the respondents by age

The majority of the students surveyed $(87.9 \%, 211 / 240)$ were single, $9.6 \%(23 / 240)$ were married and $2.5 \%$ (6/240) were divorced (Fig. 3). 92.5\% (222/240) of the interviewed students had no children.

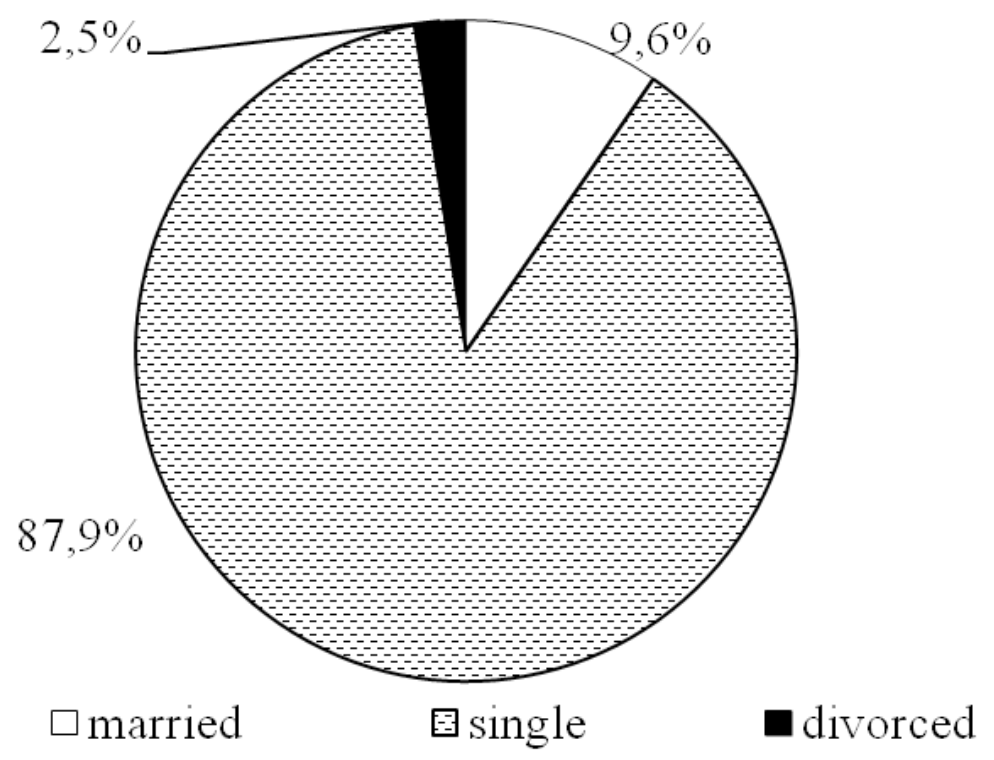

Fig. 3. Distribution of the respondents by marital status 
The majority of the respondents $(95 \%, 228 / 240)$ are aware of the risk for developing breast cancer. It is a very high result, although about 5\% (12/240) of the interviewed students did not have this information or found it difficult to answer the question.

When answering the question about the risk factors for breast cancer, only $10.4 \%$ $(25 / 240)$ of the students participating in the survey marked all the responses, almost every third girl $(28 \%, 67 / 240)$ chose age as the primary risk factor for this pathology, every sixth of the interviewed students believes family history $(14.6 \%, 35 / 240)$ and excess body weight and low physical activity $(16.7 \%, 40 / 240)$ to be an important risk factor for breast cancer; only 1.3\% (3/240) of the respondents chose lack of childbearing and pregnancy after 30 years of age. It is worth noting the somewhat higher level of awareness of the fixed risk factors (independent of people) in comparison with the modifiable risk factors (those that can be changed) (Table 1).

T a b l e 1

The students' awareness of the risk factors for breast cancer

\begin{tabular}{|l|c|c|}
\hline \multirow{2}{*}{$\begin{array}{l}\text { Risk factors for developing breast cancer } \\
\text { Age over 40 }\end{array}$} & $\begin{array}{c}\text { Number of respondents who chose a } \\
\text { certain answer }\end{array}$ \\
\cline { 2 - 3 } percent, \% & number of persons \\
\hline Breast cancer cases among your family members & 28.0 & $67 / 240$ \\
\hline Menstrual history & 14.6 & $35 / 240$ \\
\hline Pregnancy after 30 and lack of childbearing & 6.3 & $15 / 240$ \\
\hline Use of hormone medications & 1.3 & $3 / 240$ \\
\hline Unhealthy habits (smoking, excessive alcohol use) & 8.3 & $20 / 240$ \\
\hline Excessive body weight and low physical activity & 8.3 & $20 / 240$ \\
\hline Frequent stress & 16.7 & $40 / 240$ \\
\hline All of the above & 6.3 & $15 / 240$ \\
\hline
\end{tabular}

Responding to the question about the family history $88.3 \%(212 / 240)$ of the respondents answered that there were no breast cancer cases among their relatives, while $11.7 \%(28 / 240)$ of the interviewed students had cases of this disease in their families.

About half of the respondents $(56.7 \%, 136 / 240)$ believe that they are not at risk of developing breast cancer. Every fourth girl $(25.8 \%, 62 / 240)$ finds it difficult to answer this question, and almost every sixth $(17.5 \%, 42 / 240)$ believes that she is at risk of developing this disease. Thus, it should be noted that the level of breast cancer-related anxiety among the female students is relatively low.

Most of the respondents $(83.3 \%, 200 / 240)$ are familiar with the method of breast selfexamination (BSE), although every sixth girl $(16.7 \%, 35 / 240)$ does not know or does not have enough information about the method of self-examination (Table.3). However, despite the quite high extent of BSE awareness, only every third respondent $(29.2 \%, 70 / 240)$ does BSE regularly, 39.1\% (94/240) of the interviewed students sometimes do it, about one third of the interviewed girls $(31.7 \%, 76 / 240)$ do not do it or find it difficult to answer this question (Table.2). 
Ta b 1 e 2

Distribution of respondents according to their awareness of the Breast SelfExamination method and to how regularly it is done

\begin{tabular}{|l|c|c|c|c|}
\hline \multirow{2}{*}{\begin{tabular}{l} 
Question \\
\multirow{2}{*}{ Answer }
\end{tabular}} & \multicolumn{2}{|c|}{$\begin{array}{c}\text { Are you familiar with the method of Breast } \\
\text { Self-Examination? }\end{array}$} & $\begin{array}{c}\text { Do you practice Breast Self-Exam- } \\
\text { ination? }\end{array}$ \\
\cline { 2 - 5 } & pumber of respondents who chose a certain \\
answer & $\begin{array}{c}\text { Number of respondents who chose a } \\
\text { certain answer }\end{array}$ \\
\hline Yes & 83.3 & number of persons $\%$ & $\begin{array}{c}\text { number of } \\
\text { persons }\end{array}$ \\
\hline Sometimes & - & $200 / 240$ & 29.2 & $70 / 240$ \\
\hline No & 6.3 & - & 39.1 & $94 / 240$ \\
\hline $\begin{array}{l}\text { Difficult to } \\
\text { answer }\end{array}$ & 10.4 & $15 / 240$ & 24.6 & $59 / 240$ \\
\hline
\end{tabular}

All the measures to reduce the risk for developing breast cancer are taken by only $5 \%$ $(12 / 240)$ of the interviewed students, $2.1 \%(5 / 240)$ do not take any measures. A considerable part of the respondents choose control of their emotional state and regular gynecological checkups $(17.5 \%, 42 / 240)$, giving up unhealthy habits $(15 \%, 36 / 240)$, active lifestyle and weight control $(14.2 \%, 34 / 240)$. However, only $2.9 \%(7 / 240)$ of the girls realize that breastfeeding, pregnancy and childbirth before age 30 reduce the risk for developing breast cancer (Table. 3).

\section{Distribution of the respondents according to the measures taken to reduce the risk for breast cancer}

\begin{tabular}{|l|c|c|}
\hline \multirow{2}{*}{ Measures to reduce the risk for breast cancer } & \multicolumn{2}{c|}{$\begin{array}{c}\text { Number of respondents who chose a certain } \\
\text { answer }\end{array}$} \\
\cline { 2 - 3 } & percent, \% & number of persons \\
\hline Give up unhealthy habits, first of all smoking & 15.0 & 36 \\
\hline Increase physical activity & 14.2 & 28 \\
\hline Eat healthy & 11.7 & 34 \\
\hline Maintain a healthy body weight & 14.2 & 42 \\
\hline Control of one's emotional state & 17.5 & 42 \\
\hline Regular gynecological exams & 17.5 & 7 \\
\hline Try to have children at a young age and breastfeed them & 2.9 & 12 \\
\hline All of the above & 5.0 & 5 \\
\hline Do nothing & 2.1 & \\
\hline
\end{tabular}

About half of the interviewed students $(46.3 \%, 111 / 240)$ visit their gynecologist regularly, $53.7 \%$ (129/240) do not do this or find it difficult to answer this question.

The absolute majority of the interviewed students $(92.7 \%, 222 / 240)$ believe that they do not have any breast problems, 5\% (12/240) find it difficult to answer this question, and $2.5 \%(6 / 240)$ of the girls - according to their responses - have some breast problems.

More than half of the interviewed students $(63.3 \%, 152 / 240)$ would like to do a mammography or breast ultrasound, which is an indicator of the girls' attitude to their 
health and their interest in this matter. However, every fourth girl $(23.3 \%, 56 / 240)$ did not indicate readiness to do that; every eighth $(13.3 \%, 32 / 240)$ finds it difficult to answer this question.

Thus, the results of the study reveal that for a considerable part of the respondents more work is needed in order to create and strengthen their motivation to lead a healthy lifestyle. Moreover, it will facilitate the process of filling in information gaps regarding breast cancer and methods for its detection, make girls change their attitude to this matter and encourage them to take more responsibility for their own health.

\section{Con c l u s i o n s}

The results of the study show the insufficient awareness level regarding the risk factors causing breast cancer development as well as the low level of caution regarding the possibility of development of this type of cancer.

Furthermore, the present study emphasized the necessity to introduce into the education process the so called "educational" questionnaires, which would not only help find out the extent of students' awareness of a certain topic but also expand their knowledge of this topic.

\section{Ref e r e n c e s}

1. Hollern D., Swiatnicki M., Andrechek E. Histological subtypes of mouse mammary tumors reveal conserved relationships to human cancers // PLOS Genetics 2018 [Electronic resource]. - Mode of access: https://journals.plos.org/plosgenetics/article?id=10.1371/journal.pgen.1007135. https://doi.org/10.1371/ journal.pgen.1007135

2. Annual Report to the Nation 2019: Overall Cancer Statistics // National Cancer Institute 2019 [Electronic resource]. - Mode of access: https://seer.cancer.gov/report_to_nation/statistics.html.

3. Yazdani A., Dorri S., Atashi A. et al. Bone Metastasis Prognostic Factors in Breast Cancer // Breast Cancer: Basic and Clinical Research. - 2019. - N 13. - P. 1-7. https://doi.org/10.1177/1178223419830978

4. Manai M., Finetti P., Mejri N. Inflammatory breast cancer in 210 patients: A retrospective study on epidemiological, anatomo-clinical features and therapeutic results // Molecular and clinical oncology. 2019. - N 10 (2). - P. 223-230. https://doi.org/10.3892/mco.2018.1773

5. Sharen G., Yaojun P., Haidong C. et al. Prognostic value of GLUT-1 expression in pancreatic cancer: results from 538 patients // Oncotarget. - 2017. - N 8. - P. 19760-19767. https://doi.org/10.18632/ oncotarget. 15035

6. Ludmir E. B., Mainwaring W., Lin T. A. et al. Factors Associated With Age Disparities Among Cancer Clinical Trial Participants // JAMA Oncology. - 2019 [Electronic resource]. - Mode of access: https://jamanetwork.com/journals/jamaoncology/fullarticle/10.1001/jamaoncol.2019.2055. https://doi. org/10.1001/jamaoncol.2019.2055

7. Seer is an authoritative source for cancer statistics in the United States. // National Cancer Institute 2019 [Electronic resource]. - Mode of access: https://seer.cancer.gov.

Надійшла до редакції 17 жовтня 2019 р. Прийнято до друку 29 жовтня 2019 р.

O. V. Kryvoviaz (https://orcid.org/0000-0001-5441-1903),

I. K. Shcherba (https://orcid.org/0000-0001-7090-2868),

Yu. O. Tomashevska (https://orcid.org/0000-0001-9708-1887),

V. V. Kudria (https://orcid.org/0000-0001-6613-8035)

Pirogov National Memorial Medical University, Vinnytsya

STUDENTS' AWARENESS OF BREAST CANCER RISK FACTORS (RESULTS OF A SOCIOLOGICAL STUDY)

Key words: breast cancer, risk factors, anonymous survey, questionnaire

A B S T R A C T

The organization of services and measures aiming to improve prevention, diagnosis and treatment of women who suffer from cancer of reproductive organs remains a pressing issue which has to be addressed at the state level. The rates of breast cancer incidence and mortality in Ukraine are respectively $45 \%$ and $56 \%$ higher in comparison to the European countries. Each fourth woman is diagnosed with breast cancer at stage 3 or 4 , when the effectiveness of treatment is greatly reduced. Early detection of the disease increases the chances for successful treatment in $98.1 \%$ of cases. 
The aim of the work was to determine the extent of awareness of the breast cancer (BC) prevention methods among the female students as well as to reveal any risk groups for this disease.

The survey material consisted of 240 completed questionnaires. They included thirteen questions about the existence of risk groups and developmental factors, the presence of breast cancer among the relatives of respondents, the methodology of breast self-examination and breast cancer prevention measures. The study used sociological and medical-statistical methods.

The results of the survey reveal the majority of the respondents are aware of the risk for developing breast cancer, only $10.4 \%$ marked all the responses about the risk factors for breast cancer, $56.7 \%$ believe that they are not at risk of developing breast cancer. Most of the respondents are familiar with the method of breast self-examination. However, only every third respondent does it regularly. About half of the interviewed students visit their gynecologist regularly. Moreover, it will facilitate the process of filling in information gaps regarding breast cancer and methods for its detection, make girls change their attitude to this matter and encourage them to take more responsibility for their own health.

The results of the study show the insufficient awareness level regarding the risk factors causing breast cancer development as well as the low level of caution regarding the possibility of development of this type of cancer.

Furthermore, the present study emphasized the necessity to introduce into the education process the so called «educational» questionnaires, which would not only help find out the extent of students' awareness of a certain topic but also expand their knowledge of this topic.

О. В. Кривов'яз (https://orcid.org/0000-0001-5441-1903),

I. К. Щерба (https://orcid.org/0000-0001-7090-2868),

Ю. О. Томашевська (https://orcid.org/0000-0001-9708-1887),

В. В. Кудря (https://orcid.org/0000-0001-6613-8035)

Вінницький національний медичний університет ім. М. І. Пирогова, м. Вінниия

ОБІЗНАНІСТЬ СТУДЕНТОК ЩОДО ФАКТОРІВ РИЗИКУ РАКУ МОЛОЧНОЇ ЗАЛОЗИ (РЕЗУЛЬТАТИ СОЦІОЛОГІЧНОГО ДОСЛІДЖЕННЯ)

Ключові слова: рак грудної залози, фактори ризику, анонімне опитування, анкета-опитувальник А Н О Т А Ц І Я

Організація заходів, спрямованих на покращення профілактики, діагностики та лікування жінок, які страждають на рак репродуктивних органів, залишається нагальним питанням, яке має вирішуватися на державному рівні. Рівень захворюваності на рак молочної залози та смертність в Україні відповідно на $45 \%$ та 56\% вищі порівняно з європейськими країнами. У кожної четвертої жінки діагностують рак молочної залози на 3 або 4 стадії, коли ефективність лікування значно знижується. Раннє виявлення захворювання збільшує шанси на успішне лікування у 98,1\% випадків.

Мета дослідження полягала у визначенні ступеня обізнаності студенток про методи профілактики раку молочної залози, а також виявлення груп ризику щодо цього захворювання.

Матеріалом дослідження були 240 заповнених бланків анкет. Вони складалися з тринадцяти питань щодо існування груп ризику та факторів розвитку, наявності випадків раку молочної залози серед родичів респондентів, методики самообстеження молочної залози та заходів профілактики раку молочної залози. У дослідженні було використано соціологічний та медико-статистичний методи.

Результати опитування свідчать, що більшість опитаних знають про ризик розвитку раку молочної залози, лише 10,4\% відзначили всі відповіді про фактори ризику раку молочної залози, $56,7 \%$ вважають, що їм не загрожує розвиток цього типу раку. Більшість респондентів знайомі 3 методом самообстеження молочної залози. Однак лише кожна третя респондентка робить це регулярно. Близько половини опитаних студенток регулярно відвідують гінеколога. Більше того, це полегшить процес заповнення інформаційних прогалин щодо раку молочної залози та методів його виявлення, змусить дівчат змінити своє ставлення до цього питання та спонукатиме їх брати більше відповідальності за власне здоров'я.

За результатами дослідження було встановлено недостатній рівень інформованості про фактори ризику розвитку раку молочної залози та низьку настороженість щодо ймовірності виникнення цього типу раку. Крім того, в дослідженні наголошено на необхідності впровадження в навчальний процес так званих «освітніх» анкет, які не лише допоможуть з'ясувати ступінь обізнаності студентів, а також дадуть можливість розширити їхні знання з цієї теми. 
Е. В. Кривовяз (https://orcid.org/0000-0001-5441-1903),

И. К. Щерба (https://orcid.org/0000-0001-7090-2868),

Ю. А. Томашевская (https://orcid.org/0000-0001-9708-1887),

В. В. Кудря (https://orcid.org/0000-0001-6613-8035)

Винниикий национальный медицинский университет им. Н. И. Пирогова, г. Винница

ОСВЕДОМЛЕННОСТЬ СТУДЕНТОК О ФАКТОРАХ РИСКА РАКА МОЛОЧНОЙ ЖЕЛЕЗЫ

(РЕЗУЛЬТАТЫ СОЦИОЛОГИЧЕСКОГО ИССЛЕДОВАНИЯ)

Ключевые слова: рак молочной железы, факторы риска, анонимный опрос, анкета-опросник

А Н Н О Т А ЦИ Я

Организация мероприятий, направленных на улучшение профилактики, диагностики и лечения женщин, страдающих раком репродуктивных органов, остается актуальным вопросом, который должен решаться на государственном уровне. Уровень заболеваемости раком молочной железы и смертность в Украине соответственно на $45 \%$ и $56 \%$ выше по сравнению с европейскими странами. У каждой четвертой женщины диагностируют рак молочной железы на 3 или 4 стадии, когда эффективность лечения значительно снижается. Раннее выявление заболевания увеличивает шансы на успешное лечение в $98,1 \%$ случаев.

Цель исследования заключалась в определении степени осведомленности студенток о методах профилактики рака молочной железы, а также выявление групп риска этого заболевания.

Материалом исследования были 240 заполненных бланков анкет. Они состояли из тринадцати вопросов о существовании групп риска и факторов развития, наличия случаев рака молочной железы среди родственников респондентов, методики самообследования молочной железы и мер профилактики рака молочной железы. В исследовании были использованы социологический и медико-статистический методы.

Результаты опроса показывают, что большинство опрошенных знают о риске развития рака молочной железы, только $10,4 \%$ отметили все ответы о факторах риска рака молочной железы, $56,7 \%$ считают, что им не грозит развитие этого типа рака. Большинство респондентов знакомы с методом самообследования молочной железы. Однако лишь каждая третья респондентка делает это регулярно. Около половины опрошенных студенток регулярно посещают гинеколога. Более того, это облегчит процесс заполнения информационных пробелов о раке молочной железы и методах его выявления, заставит девушек изменить свое отношение к этому вопросу и будет побуждать их более ответственно относится к собственному здоровью.

В результате исследования установили недостаточный уровень информированности о факторах риска развития рака молочной железы и низкую настороженность к вероятности возникновения этого типа рака. Кроме того, в исследовании подчеркивается необходимость внедрения в учебный процесс так называемых «образовательных» анкет, которые не только помогут установить степень осведомленности студентов, но и дадут возможность расширить их знания по этой тематике.

Corresponding author: 16124sk@gmail.com

(Olena Kryvoviaz) 